\title{
Towards a Structural Model Connecting Hard Skills, Soft Skills and Job Conditions and the IS Professional: The Student Perspective
}

\author{
Rodney Turner \\ Victoria University, Melbourne, Australia
}

\author{
rod.turner@vu.edu.au
}

\begin{abstract}
The IS professional is a person endowed with certain professional skills and attributes usually formally obtained through an education process. The IS professional may also have formal skills in peripheral, non technical areas that may too be obtained through a formal education process. This is typical now in the education of IS students who are aspiring IS professional. In addition they come with a range of soft skills that may be attitudinal and influenced by life and work experiences. This paper suggests that these skills, attributes and work environment do not sit in isolation from each other, but interact in an as yet unmeasured way. How this happens with students studying towards an IS qualification is discussed here and a structural model is developed to explain the interactions. The value of this research is that a picture is presented that shows the interactions between these important elements in a quantitative way.
\end{abstract}

Keywords: Information Systems, IS professional, IS graduates, technical skills, soft skills, hard skills, structural model

\section{Introduction}

The IS professional is a person who is endowed with technical skills usually formally learned at university, has some other non-technical academic knowledge studied during the course. The IS professional also has personal qualities and attributes that are sometimes intrinsic to the individual and sometimes developed and enhanced during the education process and is likely to have some concerns and expectations surrounding the work environment. These qualities and qualifications are not isolated from each other but, the author suggests, interact and affect the individual.

There has been a great deal of work published in recent years on a number of issues concerning the education of the IS professional. These studies include a number concentrating on curriculum issues. Others have reported on the perceptions of what skills and competencies an IS professional should have from the position of individual stakeholders such as academics, employers, students and others. There have been several studies concerning the comparing the different views of the various stakeholders. Other studies have investigated the importance of soft skills in the development of the IS professional from different perspectives. Most of the work reported

Material published as part of this journal, either on-line or in print, is copyrighted by Informing Science. Permission to make digital or paper copy of part or all of these works for personal or classroom use is granted without fee provided that the copies are not made or distributed for profit or commercial advantage AND that copies 1) bear this notice in full and 2) give the full citation on the first page. It is permissible to abstract these works so long as credit is given. To copy in all other cases or to republish or to post on a server or to redistribute to lists requires specific permission from the publisher at Publisher@InformingScience.org ranks the importance of technical skills or has compared earlier studies and the current situation regarding competencies desired in IS graduates. Examples of such works are discussed in previous studies below.

Where this current research differs lays in the application of structural 
modelling methods to develop a model which links several key features, allowing the direct comparison of these features. This paper presents several optional models and evaluates each before selecting one. The outcome is a model which fits the data and which successfully relates educational skills (both technical and non-technical), soft skills and personal attributes and work attributes.

\section{Previous Studies}

The formal body of knowledge that is recommended for IS graduates to possess is outlined in a number of papers (Davis, Feinstein, Gorgone, Longenecker, \& Valacich, 2001; Davis, Gorgone, Couger, Feinstein, \& Longenecker, 1997; Underwood, 1997). These publications provide guidance for educators in designing courses preparing IS students for the workplace.

Much work has been done investigating skill requirements of IS graduates including soft skills (Ross \& Ruhleder, 1993; Van Slyke, Kittner, \& Cheney, 1997), hard skills (Cappel, 2001/2002; Turner \& Lowry, 1999a, b, 2001a, 2003) and job features (McLean, Tanner, \& Smits, 1991; Turner \& Lowry, 2000, 2001c) that are motivating factors to IS graduates. Some of these compare various stakeholders such as academics and industry (Cappel, 2001/2002) student perceptions (Mawhinney, Cale. \& Callaghan, 1990).In the main they have been descriptive in nature covering curriculum emphasis, importance of skills rated in order of importance.

Gupta \& Wachter, (1998) suggest the need for IS students to develop skills and abilities in various areas including teamwork, creativity and communication and propose a capstone course to achieve these aims. Kakabadse \& Korac-Kakabadse, (2000) highlight the changing role of the IS/IT professional and identifies the skills/competencies required for development in the early twenty first century.

Determining those skills employers of new IS graduates seek is important for educators in designing curricula and advising students. Van Slyke et al. (1997) found that specific technical skills were less important than basic technical skills and non-academic skills. Doke \& Williams (1999) in a study across various IS job classifications found that systems development skills and interpersonal skills were common across classifications but programming skills were more important for entry level IS positions. Similar results (Turner \& Lowry, 1999a) were obtained in pilot study of 102 students and 54 employers of IS graduates. An earlier study (McLean et. al., 1991) found more concern with hygiene factors (income, security, etc.). Wrycza, Usowicz, Gabor \& Verber (1999) found the knowledge and skills for small businesses, is different from that of larger enterprises. Further that found that contemporary firms had a stronger need for IS specialists than they did for computer programmers.

Several authors have attempted to develop a standard list of technical skills that identify a typical IT professional. Examples include Rada, (1999) who proposed a portfolio of forty technical skills and Todd, McKeen, \& Gallupe (1995) who performed a content analysis of IS job advertisements over a twenty year period from 1970 until 1990.

Litecky \& Arnett (2001) developed a list of thirty-eight technical skills that were in demand for a typical IT professional. These authors carried out a content analysis of 20,000 job advertisements that appeared in newspapers and the Internet over a ten period from nine major metropolitan areas across the US.

The education sector provides core skills for industry to develop and to maintain competitive advantage but the onus is on the IT industry to obtain skilled workers and to train existing staff and provide opportunities for the new entrants (NOIE, 1999). Yet IS education often is seen as concentrating too much on a narrow set of technical skills (Ross \& Ruhleder, 1993). (Lee, Yen, Havelka, \& Koh (2001) note however that "it is also not economical for schools to teach students ma- 
terial they can learn more efficiently after graduation". Ross \& Ruhleder (1993) suggest the IS curricula should concentrate on developing technical \& business skills, working in a collaborative setting, instilling a sensitivity to social and organizational impacts and to inculcate the ability to self-learn in a rapidly changing technological environment. (Ashley \& Padgett, 1997; Turner \& Lowry, 2001a) have shown that despite the call from IS employers for more business orientated skills in exiting IS students, core business subjects do not rate highly.

It has been asserted that technical skills are not the total answer in preparing IS professional (Ross \& Ruhleder, 1993). They claim that many system shortcomings arise from the fact they do not address business objectives and neither are they sensitive to user needs or concerns. Further, they suggest, programs aimed at developing IS professionals of the future must cover a wide range of skills and assist the integration of these skills in complex environments. It has been suggested that it is not sufficient for CIT graduates to just have technical capabilities but should be aware of the need for professionals to have responsibility for their work and the importance of appropriate ethical behaviours (Little et al., 1999). They further suggest a need to include these aspects in the curriculum of current CIT programmes. They discuss (Little et al., 1999) the "industry-academic gap" that leads to dissatisfaction amongst employer groups with CIT graduates. They suggest that professionalism and workplace issues, or lack of these, in CIT curricula is a reason for this gap.

Wrycza et al. (1999) state that the IS profession is being "pulled in opposite directions" one being the human orientation and the other towards the technical skill. It has been suggested that the IS/IT profession is handicapped by the differing needs of business and geography. The range of activities IS professionals are called upon to perform leads to a lack of formal career structure that matches skills with roles causing confusion among stakeholders(Hemingway \& Gough, 2000, p179) . Nevertheless, Gillard (2000) maintains that there should be two aspects of a university course that require consideration - employer expectations of graduates and student preparedness on entry to a course.

Westfall (1998) asserts "Information technology literacy must include (but is not limited to):

- knowledge that covers the breadth of the field at the current point in time

- practical, hands-on experience learning and using new information technologies

- an understanding of what makes specific new information technologies more important than others

- knowledge of economic factors and trends that will lead to new information technologies and to obsolescence or devaluation of existing technologies

- an understanding of the relationship between career choices and specific information technologies

- knowledge of the critical importance of continuous learning, and skills for maintaining and extending knowledge in this field on a self-service basis, to supplement continuing formal education and training " (Westfall, 1998)

Calitz, Watson, \& deKock (1997) endeavoured to find predictors to success in matriculating high school students. They identified several new performance and psychometric criteria useful in selecting IT students. In addition they identified non-technical skills that are important for success in a business environment including Business knowledge and social skills, and communication skills, are important criteria. They particularly note importance of English language, and especially technical English. In addition they observed that while the investigative personality type succeeds in the IT industry, the social personality type is becoming increasingly important.

An early study by Young (Young, 1996) looking at the importance of a range of technical and interpersonal skills to industry when employing new IS personnel was replicated in a study of students from differing backgrounds (Weber, McIntyre, \& Schmidt, 2001). Weber et al. (2001) found that there were differences in student perception of industry requirements that was based on 
background and gender. However both the Young and the Weber studies were restricted by the three-point scales used to gather the data.

It is clear from above that there is an interaction between the competing aspects in the development and education of IS graduates. How can these interactions be measured? The purpose of this paper is to present the results of a study utilising structural equation modelling methods to develop a model that shows the possible relationships between these areas and the emphasis that students place on these.

\section{Method}

A multipart questionnaire was devised from the literature that sought views on the importance of academic areas that are included in the curriculum of many IS degrees along with a number of others that may be regarded as useful adjunct subjects in an IS degree programme. The instrument developed was based on surveys by others (Cappel, 2001/2002; Cheney, 1988; Cheney \& Lyons, 1980; Farwell, Lee, \& Trauth, 1995; Leitheiser, 1992; Leonard, 1999; Snoke \& Underwood, 1998; Tang, Lee, \& Koh, 2001; Trauth, Farwell, \& Lee, 1993; Van Slyke et al., 1997) and modified by the authors to include some additional items. Questions covered technical topics found in undergraduate IS degree programmes, core non-IS subjects, personal skills/attributes and a number of work features and incentives that are appealing to graduates seeking employment in the field.

Paper surveys were distributed to students undertaking subjects in information systems specialisation area at three universities in Victoria. Students were asked to rate the importance of the various items from not-required through to essential using a seven point Likert scale. Due to low responses in some categories, the scale was recalibrated after data collection to a five-point scale.

The surveys were completed towards the end of the second semester. Convenience sampling was used and the response rate was high, missing only those students who were either absent on the day or who had ceased to be active in the course. One university (University A) is in the western suburbs of Melbourne and its catchment area is largely working class and underprivileged with a large proportion of students from a non-English speaking background. University B is inner city based and has a catchment area from most parts of Melbourne. The third university (University C) is a regional university with a large catchment area from the western regions of Victoria.

Demographic data students were asked to provide included age, gender, stage of course, mode of study (full/part time), and any fulltime work experience.

The data were analysed using SPSS R11 and descriptive statistics and factor analysis was reported. Structural models utilizing the SPSS data were developed using AMOS 5. This package has a number of features that allow for the rapid testing, accepting or elimination of models under consideration and this feature was utilized during the analysis.

\section{Results}

Demographic details of the students are presented in Table 1. It shows the distribution of responses by gender, age and university attended. 
There were 253 usable returns from the three universities. It has been shown (Turner \& Lowry, 2001b) that for work incentives there were no major differences in responses from students from the three universities.

Factor analysis identified nine different items. Two items were concerned with the job and its features, two were concerned with soft skills and personal qualities and five were concerned with educational matters.

Table 1: Demographic details



\section{Analysis}

Item reliability was tested using Cronbach's alpha. Item reliability was good with the overall value for each subscale exceeding the recognised benchmark value of 0.7

Exploratory factor analysis was performed on the items in the questionnaire using PCA analysis with Varimax rotation. Questions that did not clearly load onto a single factor or which did not have a value of at least 0.5 were excised. The final outcome identified nine separate factors in four separate areas of interest. Two factors (SF1W and SF2W) were identified as soft skills and these were measured by eight questions. Two factors (WF1W and WF2W) concerned work related incentives and these were measured by seven questions. Two factors (OAF1W and OAF2W) measured by eight questions were identified as non-IS academic subject areas and three factors (F1W, F2W and F3W) were identified as IS academic subjects and these were measured by eight questions. The interpretation of these factors is given in the table below.

\section{Table 2: Factor Interpretations}

\begin{tabular}{|c|c|c|}
\hline Factor & Interpretation & Emphasis \\
\hline F1W & IS academic subjects & High level applications \\
\hline $\mathrm{F} 2 \mathrm{~W}$ & IS academic subjects & Design and development \\
\hline F3W & IS academic subjects & Web related applications \\
\hline OAF1W & $\begin{array}{l}\text { Non-IS academic sub- } \\
\text { jects }\end{array}$ & Inwardly focussed core non-IS business subjects \\
\hline OAF2W & $\begin{array}{l}\text { Non-IS academic sub- } \\
\text { jects }\end{array}$ & Outwardly orientated non-IS subjects \\
\hline SF1W & Soft skill & Get on with people, communicate or stand-out \\
\hline SF2W & Soft skill & Skills acquisition and able to do job \\
\hline WF1W & Work related incentive & Environmental and comfort \\
\hline WF2W & Work related incentive & Reward related (hygiene) factors \\
\hline
\end{tabular}

Structural equation modelling requires large data sets to be truly effective and with just 253 returns there was some concern that this was too few for sensitive analysis. Because of this, composite variables were determined from the respective questions and factors that were identified. This concern was not without foundation. The basic model had 30 manifest variables requiring nearly 1300 returns (Hair, Anderson, Tatham, \& Black, 1998). Following the method outlined by Holmes-Smith and Rowe (1994), Hair et al. (1998) and Hughes, Price, \&. Marrs (1986) composite factor measurement models were developed to reduce the complexity of the model and to reduce the number of returns required for a reliable model. The various latent variables in the model are replaced by the calculated composite variable that is then treated as a distinct manifest 
or measurement variable (Hair et. al., 1998). This approach reduced the number of returns to approximately 150 - a more realistic figure.

The method selected for model fitting was the maximum likelihood (ML) method that is often used in structural equation modelling (Hair et al., 1998; Wang \& Armstrong, 2001). Table 3 shows the normality tests on the various variables. According to levels suggested by Garson (n. d.) the values for kurtosis and skewness are each within the acceptable range of between \pm 2 .

As no single fit measure has been developed, a number of fit measures are usually presented. The measures and the values for an acceptable fit are presented in Table 4 (Hodgson, 1999; Murray, 1997; Schumacker \& Lomax, 1996).

Table 3: Assessment of normality (Students)

\begin{tabular}{lrrrr}
\hline Variable & min & max & skew & kurtosis \\
\hline F1W & 3.00 & 7.00 & 0.13 & -0.40 \\
F2W & 3.30 & 7.00 & 0.05 & -0.08 \\
F3W & 3.00 & 7.00 & -0.52 & -0.17 \\
OAF1W & 3.00 & 7.00 & 0.22 & -0.14 \\
OAF2W & 3.00 & 7.00 & -0.33 & -0.08 \\
SF2W & 3.76 & 7.00 & -0.45 & 0.09 \\
SF1W & 3.29 & 7.00 & -0.34 & -0.43 \\
WF1W & 3.00 & 7.00 & -0.82 & 0.64 \\
WF2W & 3.25 & 7.00 & -0.32 & -0.40 \\
\hline
\end{tabular}

Chi square is sensitive to sample size and $\mathrm{p}$ values alone should not be relied upon when sample size is larger than about 100 (Hair et al., 1998)

\section{Table 4: Structural model fit indices}

\begin{tabular}{ll} 
Test & Acceptable values \\
\hline Likelihood ratio $x^{2}$ & $\mathrm{p}>0.05$ \\
$\mathrm{X}^{2} /$ degrees of freedom (normed chi-square, & $<3.0$ \\
CMIN/DF) & $>0.9$ \\
Goodness of fit (GFI) & $>0.9$ \\
Adjusted goodness of fit (AGFI) & Close to zero \\
Root mean square residual (RMR) & $<0.08$, and preferably $<$ \\
Root mean square error of approximation & 0.06 \\
(RMSEA) & $>0.9$ \\
Tucker Lewis Index (TLI) & $>0.9$ \\
Normed Fit Index (NFI) & $>0.9$ \\
Comparative Fit Index (CFI) &
\end{tabular}

\section{Model Development}

Several different models were tested against the data and three of these are presented below. Model 1 (see Figure 1) has three latent variables that are indicated by the respective composite variables referred to in Table 2. In this version, the latent variable education consists of a single latent construct made of the three variables that are technical in nature (F1W-F3W) and the two non-technical academic areas $(\mathrm{OF} 1 \mathrm{~W}, \mathrm{OF} 2 \mathrm{~W})$.

Although this model has some merit and some fit measures are acceptable, the discrepancy function (CMIN/DF) although still within acceptable values is a little high at 2.48. However RMSEA (0.077) and TLI (0.898) are both outside preferred ranges and therefore an alternative model is sought. The remaining fit measures AGFI (0.911), GFI (0.949) and RMR (0.038) each fall within acceptable values. 


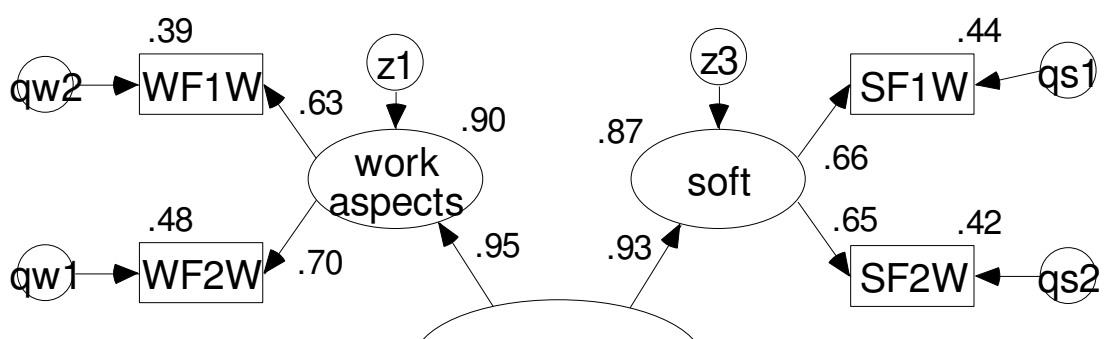

IS Professional

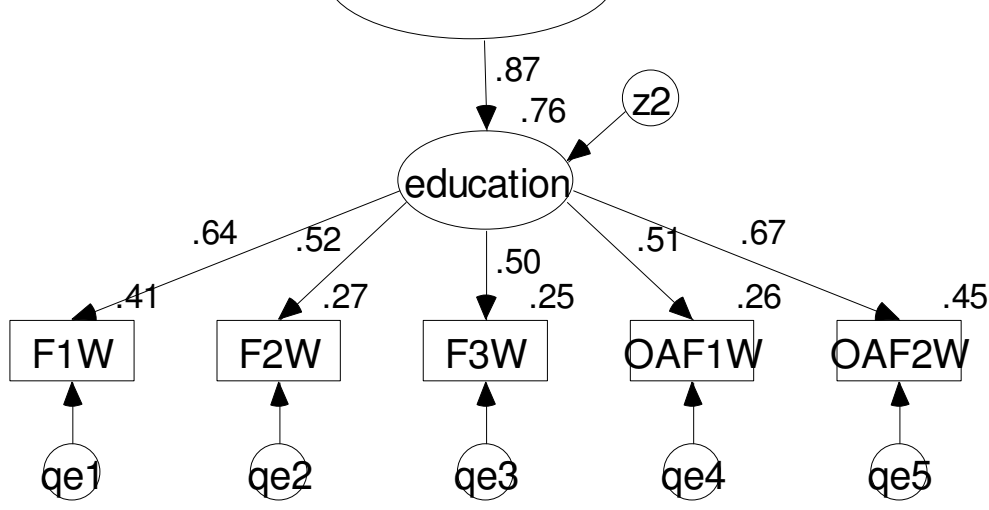

$$
\begin{gathered}
\text { Chi Square }=64.466 \quad \mathrm{df}=26 \quad \mathrm{p}=.000 \\
\text { Discrep. }=2.479 \\
\text { AGFI }=.911 \text { GFI }=.949 \quad \mathrm{TLI}=.898 \\
\text { RMSEA }=.077 \text { RMR }=.038
\end{gathered}
$$

\section{Figure 1: Alternative Model 1}

The second model considered here (see Figure 2) also has three latent variables. In this version the education latent variable is split into two separate latent variables - IS ed which refers to IS technical education, and non-IS ed which refers to other more business orientated studies such as accounting and law.

The variable soft is retained unchanged but work related variables WF1 and WF2W are not linked via the work aspects latent variable. Instead they relate directly to the variable IS professional.

The outcome is a model that has a substantially better fit to the data. In this case the discrepancy function (CMIN/DF) is good (1.647) and fit measures AGFI (0.938), GFI (0.968), TLI (0.955) and RMR (0.039) are each within the generally accepted range (Table 4). The value for RMSEA (0.051) is slightly high with the HI90 value of (0.076) and this prompts the testing of a third variant of the model. This is supported by the relatively high value for the standardised regression value IS Professional --> soft of 0.91 which may suggest the existence of multicollinearity. 


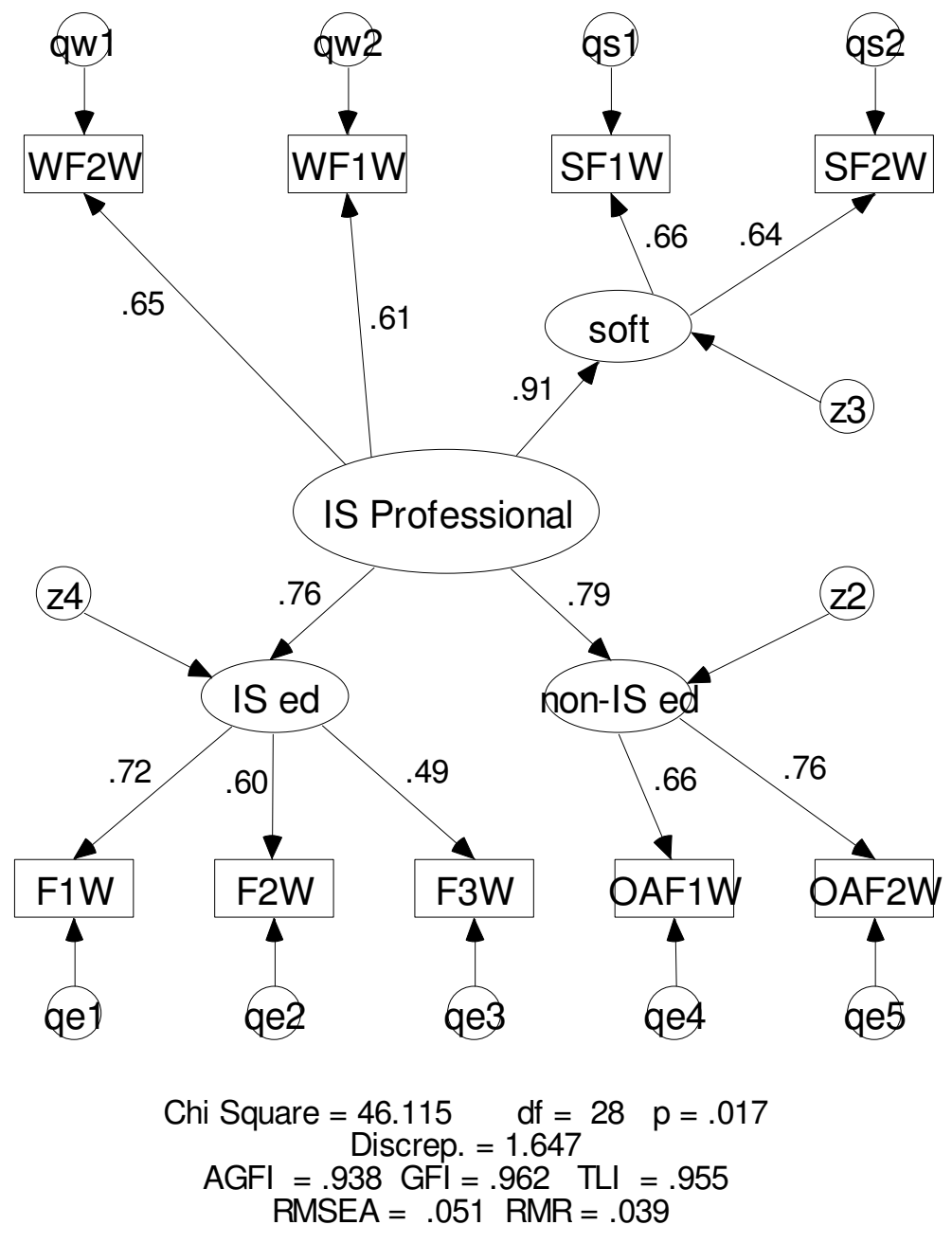

Figure 2: Alternative Model 2

\section{Final model}

The third version of the model is presented in Figure 3. In this version there are the four latent variables appearing in the first two versions. Work Aspects and soft are the same as for model 1 (Figure 1) and $I S E d$ and non-Is $E d$ are from model 2 (Figure 2). When this model is applied to the data a substantial improvement in fit is observed. As can be seen from Figure 3, all the fit measures lie within acceptable values as follows: discrepancy function (CMIN/DF- 1.407), RMR (0.025) RMSEA (0.04) with LO90 $=0.00$, HI90=0.07, AGFI (0.947), TLI (.972) and p=0.09. Although some minor improvements are possible after inspection of the modification indices, for the sake of model parsimony no further changes were incorporated. The only change incorporated into the model to improve the fit was allowing error terms $\mathrm{z} 1$ and $\mathrm{z} 2$ to co vary. This can be justified on substantive theoretical grounds with soft skills and work aspects having some overlap especially through WF1W relating to working environment. 


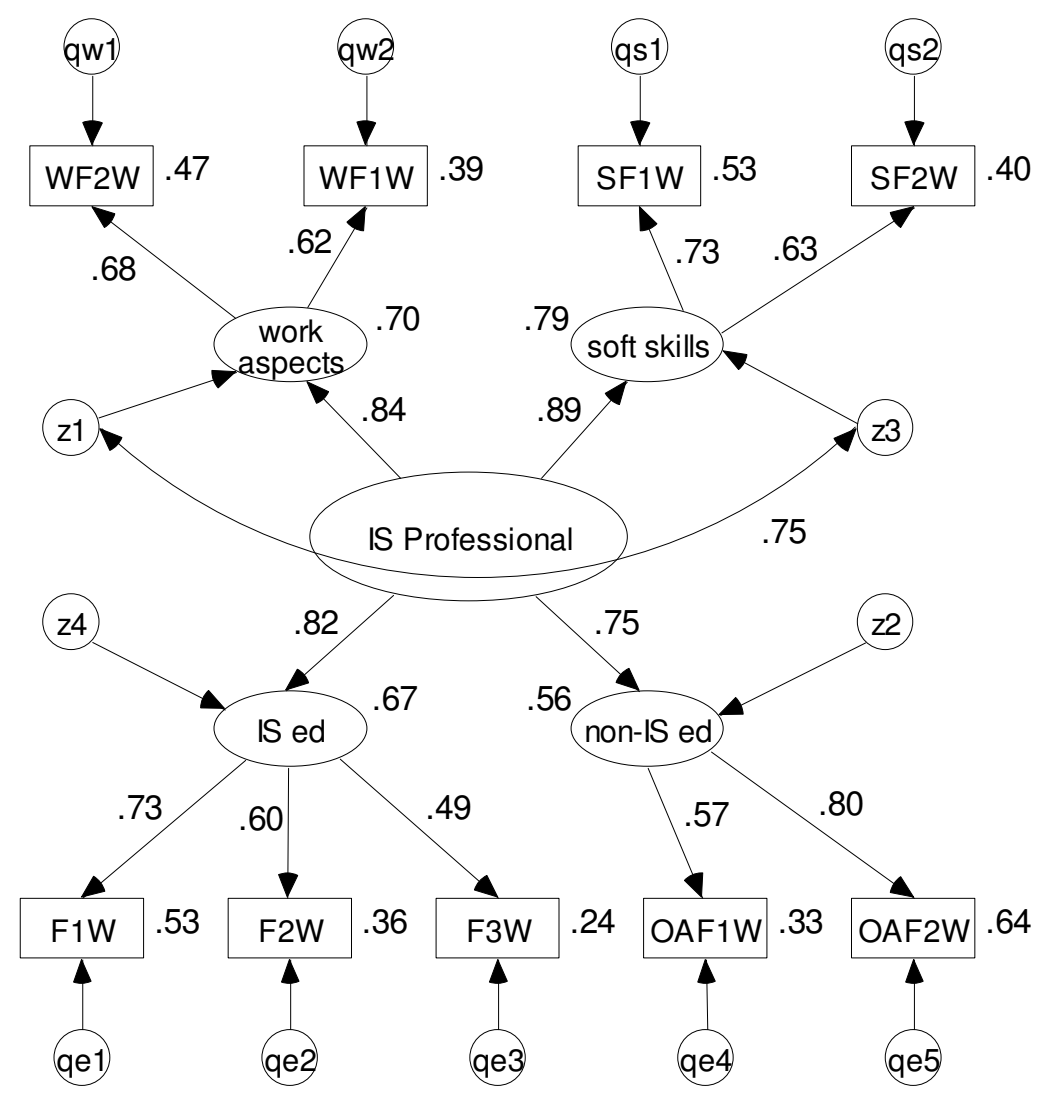

$$
\begin{array}{r}
\text { Chi Square }=32.358 \quad \mathrm{df}=23 \mathrm{p}=.093 \\
\text { Discrep. }=1.407 \\
\mathrm{AGFI}=.947 \mathrm{GFI}=.973 \mathrm{TLI}=.972 \\
\mathrm{RMSEA}=.040 \mathrm{RMR}=.025
\end{array}
$$

Figure 3: Final Model 3

Apart form the good fit indicators, the path parameters are each statistically significant with $\mathrm{p}<0.001$. These are indicated in the unstandardized regression weights (Table 5) given below. As can be seen from the table the critical ratios (CR) for the paths are greater than 1.96 and so are retained in the model.

Table 5: Regression Weights (final model)

\begin{tabular}{|ll|rrrr|}
\hline & & Estimate & S.E. & C.R. & P \\
\hline non-IS ed & $<--$ IS Professional & .695 & .138 & 5.034 & $* * *$ \\
IS ed & $<--$ IS Professional & .968 & .154 & 6.273 & $* * *$ \\
soft skills & $<--$ IS Professional & 1.000 & & & \\
work_aspects $<---$ IS Professional & .774 & .100 & 7.703 & $* * *$ \\
SF2W & $<--$ - soft skills & .716 & .084 & 8.497 & $* * *$ \\
F1W & $<--$ IS ed & 1.000 & & & \\
F3W & $<--$ IS ed & .749 & .121 & 6.177 & $* * *$ \\
OAF2W & $<---$ non-IS ed & 1.286 & .211 & 6.109 & $* * *$ \\
\hline
\end{tabular}




\begin{tabular}{|ll|rrrr|}
\hline & & Estimate & S.E. & C.R. & P \\
\hline SF1W & $<---$ soft skills & 1.000 & & & \\
F2W & $<---$ IS ed & .750 & .105 & 7.156 & $* * *$ \\
OAF1W & $<---$ non-IS ed & 1.000 & & & \\
WF1W & $<---$ work_aspects & .961 & .123 & 7.813 & $* * *$ \\
WF2W & $<---$ work_aspects & 1.000 & & & \\
\hline
\end{tabular}

Table 6 shows the standardised regression coefficients determined for the student data. Values for the regression weight below 0.3 are considered as weak, between 0.3 and 0.5 as mild and above these values as strong (Holmes-Smith, 2000). From Table 6 it can be seen that all regression weights are at sound and have values above 0.4.

Squared multiple correlations ( $\mathrm{R}^{2}$ values) presented in Table 7 are, with the exception of F3W, above the recommended minium value of 0.3 suggesting item reliability is good (Holmes-Smith, 2000). As a further indicator of the model being, standardized residual covariance values between indicators are each below the critical value of 2.58 (Table 7) suggested by (Hair et. al., 1998) confirming they are significant at the 0.05 level. The low value for this variable may be due to it being measured by just two questions.

\begin{tabular}{|c|c|c|}
\hline \multicolumn{3}{|c|}{\begin{tabular}{|c} 
Table 6: Standardized Regression Weights \\
(final model)
\end{tabular}} \\
\hline & & Estimate \\
\hline non-IS ed & $<---$ IS Professional & .748 \\
\hline IS ed & $<---$ IS Professional & .816 \\
\hline soft skills & $<---$ IS Professional & .892 \\
\hline work_aspects & <--- IS Professional & .836 \\
\hline SF2W & $<---$ soft skills & .631 \\
\hline F1W & $<---$ IS ed & .730 \\
\hline F3W & $<---$ IS ed & .491 \\
\hline OAF2W & $<---$ non-IS ed & .797 \\
\hline SF1W & $<---$ soft skills & .728 \\
\hline F2W & $<---$ IS ed & .599 \\
\hline OAF1W & $<---$ non-IS ed & .573 \\
\hline WF1W & $<---$ work_aspects & .624 \\
\hline WF2W & $<---$ work_aspects & .684 \\
\hline
\end{tabular}

\begin{tabular}{|l|c|}
\hline \multicolumn{2}{|c|}{$\begin{array}{c}\text { Table 7: Squared Multiple } \\
\text { Correlations (final model) }\end{array}$} \\
\hline & Estimate \\
\hline work_aspects & .699 \\
non-IS ed & .559 \\
IS ed & .666 \\
soft skills & .795 \\
OAF1W & .328 \\
F1W & .534 \\
F2W & .359 \\
F3W & .241 \\
OAF2W & .636 \\
SF2W & .398 \\
SF1W & .531 \\
WF1W & .390 \\
WF2W & .467 \\
\hline
\end{tabular}


Table 8: Standardized Residual Covariances (final model)

\begin{tabular}{|l|rrrrrrrrr|}
\hline & OAF1W & F1W & F2W & F3W & OAF2W & SF2W & SF1W & WF1W & WF2W \\
\hline OAF1W & -1.205 & & & & & & & & \\
F1W & -.726 & .085 & & & & & & & \\
F2W & -.067 & .646 & -.004 & & & & & & \\
F3W & .875 & -.788 & -.014 & .039 & & & & & \\
OAF2W & -1.080 & .476 & -.780 & .294 & -.363 & & & & \\
SF2W & -1.926 & .809 & -.607 & 1.317 & .601 & .119 & & & \\
SF1W & -1.002 & .954 & .580 & 1.035 & .163 & .781 & 1.108 & & \\
WF1W & -1.566 & -.233 & -.666 & .475 & .023 & -.400 & .978 & .000 & \\
WF2W & -1.280 & -.825 & -1.335 & 1.132 & -1.454 & .056 & 1.842 & .442 & -.130 \\
\hline
\end{tabular}

\section{Discussion}

Educational issues rate very strongly as would be expected from students still heavily involved with their studies. What is surprising and of possible concern for educators is the lack of connection between the technical areas and the non-technical business subjects that are part of the IS curriculum.

The structural component of the model indicates strong contributions from each are with a slightly lower emphasis on non-IS educational matters. Somewhat unexpectedly the variable F3W which relates to web development matters is relatively weak compared with all of the others.

Soft skills are very important in this model and this has been known for some time that employers are seeking a variety of these skills in their new employees. This model supports the importance that these qualities have in the overall picture of what constitutes an IS employee. More importantly perhaps is the indication that the work situation appears to influence quite strongly these very soft skills.

The model indicates that reward related incentives (WF2W), or the so-called hygiene factors (Hertzberg, 1968) are more important than environmental factors (WF1W). There is a noticeable difference in the importance of soft skills with getting on well with people and communication (SF1W) being much stronger than skills acquisition matters (SF2W).

On education matters, there is a big difference between the traditional business related subjects such as accounting, economics and statistics referred to as inwardly focussed (OAF1W) and the more outwardly oriented subjects such as marketing and management (OAF2W). There is evidence of the importance of high level applications such as client-server application, data mining and ERP (F1W) and database application, OOP and CASE applications (F2W). However the response to web applications ecommerce $(\mathrm{F} 3 \mathrm{~W})$ was comparatively weak.

Many of the individual relationships incorporated into the model have been accepted as the norm in recent times but to the author's knowledge this is a first attempt to show the level of interaction between the factors. This is potentially quite important as it gives curriculum designers an insight into the relative importance of these factors which hereto have not been easily quantifiable.

These results relate only to the perception of students. The author anticipates extending the application to other stakeholders including academics involved in the teaching of IS students and to those already working in an IT environment in some professional capacity. These include practitioners and decision makers directly responsible for the professional activities of IS staff. Early indications suggest that this model can be applied to these groups as well. 


\section{References}

Ashley, N. W. \& Padgett, T. C. (1997). Information systems graduates: Evaluation of their IS curricula. Retrieved 10/7/2000 from http://www.westga.edu/ bquest/1998/infosys.html

Calitz, A. P., Watson, M. B., \& deKock, G. d. V. (1997). Identification and selection of successful future it personnel in a changing technological and business environment. SIGCPR 97, San Francisco CA, ACM. pp. 31-35.

Cappel, J. J. (2001/2002). Entry-level IS job skills: A survey of employers. Journal of Computer Information Systems, 42 (2, Winter), 76-82.

Cheney, P. H. (1988). Information system skill requirements: 1980 \& 1990. ACM_(4).

Cheney, P. H. \& Lyons, N. R. (1980). Information system skill requirements: A survey. MIS Quarterly, 4 (2), 35-43.

Davis, G. B., Feinstein, D. L., Gorgone, J. T., Longenecker, H. E. \& Valacich, J. S. (2001). IS2002: An update of the information systems curriculum. Retrieved 7/1/2004 from www.spatial.maine.edu/SIEWEB/IS_ModelCurriculum.pdf>

Davis, G. B., Gorgone, J. T., Couger, J. D., Feinstein, D. L. \& Longenecker, H.E. (Eds) (1997). IS'97 model curriculum and guidelines for undergraduate degree programs in information systems. The Data Base for Advances in Information Systems, 28 (1).

Doke, E. R. \& Williams, S. R. (1999). Knowledge and skill requirements for information systems professionals: An exploratory study. Journal of IS Education 10 (1), 10-18.

Farwell, D., Lee, D. M., \& Trauth, E. M. (1995). Critical skills and knowledge requirements of IS professionals: A joint academic/industry investigation. MIS Quarterly, 313-337.

Garson, G. D. (n. d.) Pa 765 statnotes: An online textbook. Retrieved 27/7/2000 from $<$ http://www2.chass.ncsu.edu/garson/pa765/statnote.htm $>$

Gillard, S. (2000). Fact or fiction: Entry-level college students are ready for an advanced computer applications course. 15th Annual Conference of the International Academy for Information Management, Brisbane Australia. 109-110.

Gupta, J. N. D. \& Wachter, R. M. (1998). A capstone course in the information systems curriculum. International Journal of Information Management, 18 (6), 427-441.

Hair, J. F., Anderson, R. E., Tatham, R. L., \& Black, W. C. (1998). Multivariate data analysis. Upper Saddle River, NJ: Prentice-Hall.

Hemingway, C. J. \& Gough, T. G. (2000). The value of information systems teaching and research in the knowledge society. Informing Science, 3 (4), 167-184.

Hertzberg, F. (1968). One more time: How do you motivate employees? Harvard Business Review, 46 (1), 53-62.

Hodgson, L. (1999). Organizational change through the mandated implementation of new information systems technology: A modified technology acceptance model. Virginia Commonwealth University

Holmes-Smith, P. (2000). Introduction to structural equation modelling. ACSPRI 2000: 143.

Holmes-Smith, P. \& Rowe, K. J. (1994). The development and use of congeneric measurement models in school effectiveness research: Improving reliability and validity of composite and latent variables for fitting multilevel and structural equation models. International Conference for School Effectiveness and Improvement. World Congress Centre, Melbourne, Australia. 18 pages.

Hughes, M. A., Price, R. L., \& Marrs, D. W. (1986). Linking theory construction and theory testing: Models with multiple indicators of latent variables. Academy of Management Review, 11 (1), 128-144.

Kakabadse, A. \& Korac-Kakabadse, N. (2000). Future role of IS/IT professionals. Journal of Management Development, 19 (2), 97-154. 
Lee, S., Yen, D., Havelka, D. \& Koh, S. (2001). Evolution of IS professionals' competency: An exploratory study. Journal of Computer Information Systems, 41 (4), 19 pages.

Leitheiser, R. L. (1992). MIS skills for the 1990s: A survey of MIS managers' perceptions. Journal of Management Information Systems, 9 (1), 69-91.

Leonard, L. (1999) Survey shows skills gap still a problem. Retrieved 23/6/2002 from $<$ http://www.itac.ca/>

Litecky, C. \& Arnett, K. (2001). An update on measurement of IT job skills for managers and professionals. Seventh Americas Conference on Information Systems. 1922-1924

Little, J. C., Granger, M. J., Boyle, R., Gerhardt-Powals, J. Impagliazzo, J., Janik, C., Kubilis, N. J., Lippert, S. K., McCracken, W. M., Paliwoda, G. \& Soja. P. (1999). Integrating professionalism and workplace issues into the computing and information technology curriculum. ITiCSE '99 Working Group Reports, 33 (4), 106-112.

Mawhinney, C. H., Cale, E. G., \& Callaghan, D. R. (1990). Freshman Expectations of Information Systems Careers Versus Their Own Careers. Journal of Information Systems Education, 3.

McLean, E. R., Tanner, J. R., \& Smits, S. J. (1991). Self-perceptions and job preferences of entry-level information systems professionals: Implications for career development. Special Interest Group on Computer Personnel Research Annual Conference, Athens, GA. 3-13

Murray, M. S. (1997). Professional self-identity of nurses and the development of empathy. Bundoora, LaTrobe University

NOIE. (1999). Providing for the future IT\&T skill needs of Australia. Retrieved 10/7/2000 from $<$ http://www.noie.gov.au/projects/e.../skills/paper_futureskills_99/htm>

Rada, R. (1999). It skills standards. Communication of the ACM, 42 (4), 21-26.

Ross, J. \& Ruhleder, K. (1993). Preparing IS professionals for a rapidly changing world: The challenge for IS educators. Special Interest Group on Computer Personnel Research Annual Conference, St Louis MO. 379-384.

Schumacker, R. E. \& Lomax, R. G. (1996). A beginner's guide to structural equation modelling. Mahwah, New Jersey: Lawrence Erlbaum Associates.

Snoke, R. \& Underwood, A. (1998). Generic attributes of IS graduates - An Australian study. Sixth European Conference on Information Systems, Aix-en-Provence, Granada: Euro-Arab Management School. 1713-1720.

Tang, H.-L., Lee, S. \& Koh, S. (2001). Educational gaps as perceived by IS educators: A survey of knowledge and skill requirements. Journal of Computer Information Systems, 41 (2), 76-84.

Todd, P. A., McKeen, J. D. \& Gallupe, R. B. (1995). The evolution of IS job skills: A content analysis of IS job advertisements from 1970-1990. MIS Quarterly, 19 (1), 1-27.

Trauth, E., Farwell, D. \& Lee. D. (1993). The IS expectation gap: Industry expectations versus academic preparation. MIS Quarterly, 17 (3), 293-307.

Turner, R. \& Lowry, G. (1999a). The complete graduate: What students think employers want and what employers say they want in new graduates. Sixteenth Pan-Pacific Business Conference, Nadi, Fiji, Pan-Pacific Business Association. 272-274.

Turner, R. \& Lowry, G. (1999b). Reconciling the needs of new information systems graduates and their employers in small, developed countries. South African Computer Journal, 24, 136-145.

Turner, R. \& Lowry, G. (2000). Motivating and recruiting intending IS professionals: A study of what attracts is students to prospective employment. South African Computer Journal, 25 (November): 132137.

Turner, R. \& Lowry, G. (2001a). The third dimension of the IS curriculum: The importance of soft skills for IT practitioners. ACIS 2001, Coffs Harbour, NSW, Australia. 683-686 
Turner, R. \& Lowry, G. (2001b). What attracts IS students to prospective employment: A study of students from three universities. IRMA, Toronto, Idea Group Publishing. 448-452.

Turner, R. \& Lowry, G. (2001c). Why did you choose this job? Comparing career motivators of IS students \& IS practitioners. ACIS 2001, Coffs Harbour, NSW, Australia. 687-691.

Turner, R. \& Lowry. G. (2003). Education for a technology-based profession: Softening the information systems curriculum. Current issues in IT education. T. McGill, IRM Press: 156-175.

Underwood, A. (1997). The ACS core body of knowledge for information technology professionals. Retrieved 21/7/2000 from <http://www.acs.org.au/national/pospaper/bokpt1.htm>

Van Slyke, C., Kittner, M. \& Cheney. P. (1997). Skill requirements for entry-level IS graduates: A preliminary report from industry. Retrieved 26/4/2000 from <http://groucho.bsn.usf.edu/ vanslyke/isecon_1.htm>

Wang, X. \& Armstrong, A. (2001). A structural model of professional commitment from the perspective of characteristics of a professional community. Victoria University: 1-18.

Weber, J. E., McIntyre, V. J. \& Schmidt, M. (2001). Explaining IS student and IS industry differences in perceptions of skill importance. Journal of Computer Information Systems, 41 (4), 79-84.

Westfall, R. D. (1998). Evaluation and assimilation skills as key knowledge aspects of information technology literacy. Retrieved 15 August 2003 from <http://www.cyberg8t.com/westfalr/it_litrc.htm>

Wrycza, S., Usowicz, T. W., Gabor, A., \& Verber, B. (1999). The challenges and directions of MIS curriculum development in respect of transformation of business requirements. ITiCSE '99, Cracow, Poland. 177-178.

Young, D. (1996). The relative importance of technical and interpersonal skills for new information systems personnel. Journal of Computer Information Systems, (Summer), 66-71.

\section{Appendix}

\section{Survey questions}

Analysis \& Design of Information Systems

LAN operations \& data communications

Web page design \& development

Knowledge base or expert systems

Able to apply $3 \mathrm{GL}$ programming languages

CASE tool applications

Project management

Client-server applications

ERP implementation \& operations

Accounting

Business ethics

Business statistics

Knowledge of foreign languages other than English

Communications \& report writing

Marketing

Mathematical modelling

International business

Ability to accept direction

Able to independently acquire new skills

Able to meet deadlines

Able to think creatively

Able to work under pressure

Business analysis skills

Information seeking skills

Have leadership potential

Have problem definition skills

Time management skills

Have written communication skills

Able to work with people of different disciplines
Business application of computers

Database design

E-commerce/E-business development

Knowledge of PC applications

Able to apply object oriented languages

Large computer system experience/knowledge

Use of operating systems

Data mining / Data warehousing

Business finance

Business or commercial law

Economics

Psychology

Management

Operations research

Organizational behaviour

Able to quickly apply new skills

Good sense of humour

Able to work as part of a team

Able to work independently

Place organizational objectives first

Able to prepare multimedia presentations

Be client focussed

Have oral presentation skills

Have problem solving skills

Willing to undergo on going professional development

Able to interact with people of different backgrounds

Able to handle concurrent tasks 
Good promotional prospects within the company

A friendly work environment

Provision for on-going training

Flexible working conditions

Supportive superiors

Fringe benefits (eg company shares, car etc)
Opportunities for travel

Challenging work assignments

An industry competitive salary

Reliable internal communications

Opportunities to expand personal skills

\section{Biography}

Rodney Turner is a lecturer in the School of Information Systems at Victoria University, Melbourne, Australia. Prior to this he has worked in industry and was a teacher for 12 years. He is a graduate of Monash University, RMIT and Melbourne CAE with qualifications in science,

mathematics education, computer education and information technology. He is currently engaged in research leading towards a PhD. His main research interests are in IS education and the skills required in a changing IS environment. He has had consulting work involving government aid projects in the Philippines and China. 